\title{
IMPLEMENTASI PENGELOLAAN ADMINISTRASI PERSONALIA PADA PT. GANDA PRABU NUSANTARA PEKANBARU
}

\author{
SUSIYANTI MEILINA \\ STISIP Imam Bonjol Padang \\ susimeilina@gmail.com
}

Abstract : Implementation of personnel administration at PT. Ganda Prabu Nusantara begins with the process of human resource planning, the activities carried out to determine the human resource needs of a company. The purpose of this research is to: 1) find out how the implementation of personnel administration management at PT.Ganda Prabu Nusantara; 2) find out what are the obstacles encountered in the implementation of personnel administration management at PT. Ganda Prabu Nusantara; 3) find out what are the efforts made to overcome obstacles in the implementation of personnel administration management at PT. Ganda Prabu Nusantara Pekanbaru. This type of research is a qualitative study using descriptive methods, namely research that tries to describe, tell, and interpret a phenomenon that occurs at the present time. . The selection of informants in this study was chosen by incidental sampling, namely sampling by taking individuals who can be reached or met .. The type of data is primary data and secondary data collected through interviews, observation, and library research. The analysis technique used is qualitative analysis. The results of this study indicate that: the implementation of personnel administration management at PT. Ganda Prabu Nusantara Pekanbaru that the planning was carried out by the chief director and his senior staff in order to obtain a mature plan regarding the programs of PT. Ganda Prabu Nusantara going forward. The conclusion is the implementation of personnel administration management at PT. Ganda Prabu Nusantara is that in recruiting employees requires a workforce planning process, because there are no mistakes in recruiting employees in recruitment. The method used by PT. Ganda Prabu Nusantara is the open and closed method. In recruiting PT. Ganda Prabu Nusantara employees have certain criteria that must be possessed by prospective employees, although there are obstacles but there are efforts to overcome them. Suggestions: expected by the leadership of PT. Ganda Prabu Nusantara in carrying out personnel administration must be increased again in order to experience maximum performance improvement; there are trainings and there are adequate incentives for employees based on policies from the leadership. Keywords: management implementation, personnel administration

\begin{abstract}
Abstrak : Pelaksanaa administrasi personalia di PT. Ganda Prabu Nusantara diawali dengan proses perencanaan sumber daya manusia yaitu kegiatan yang dilakukan untuk menentukan kebutuhan sumber daya manusia suatu perusahaan. Tujuan dari peneelitian ini adalah untuk : 1) mengetahui bagaimana implementasi pengelolaan administrasi personalia pada PT.Ganda Prabu Nusantara; 2) mengetahui apa saja kendala-kendala yang dihadapi dalam implementasi pengelolaan adminitrasi personalia pada PT. Ganda Prabu Nusantara; 3) mengetahui apa saja upaya-upaya yang dilakukan untuk mengatasi kendala dalam implementasi pengelolaan adminitrasi personalia pada PT. Ganda Prabu Nusantara Pekanbaru. Jenis penelitian ini adalah penelitian kualitatif dengan menggunakan metode deskriptif, yaitu penelitian yang mencoba menggambarkan, menuturkan, dan menafsirkan suatu fenomena yang terjadi pada masa sekarang. . Pemilihan informan dalam penelitian ini dipilih secara
\end{abstract} E-ISSN: 2657-0300 Lembaga Penelitian dan Penerbitan Hasil Penelitian Ensiklopedia 
insidental sampling yaitu pengambilan sampel dengan jalan mengambil individu siapa saja yang dapat dijangkau atau ditemui.. Jenis datanya adalah data primer dan data sekunder yang dikumpulkan melalui wawancara, observasi, dan penelitian perpustakaan. Teknik analisa yang dipakai adalah analisa kualitatif. Hasil penelitian ini menunjukkan bahwa : implementasi pengelolaan administrasi personalia pada PT. Ganda Prabu Nusantara Pekanbaru bahwa perencanaan dilakukan oleh direktur utama beserta staf seniornya agar diperoleh suatu rencana yang matang mengenai programprogram PT. Ganda Prabu Nusantara ke depannya. Adapun kesimpulan adalah Implementasi pengelolaan adminiistrasi personalia pada PT. Ganda Prabu Nusantara adalah dalaam merekrut karyawan membutuhkan proses perencanaan tenaga kerja, karena agar dalam rekrutmen tidak ada kesalahan karyawan yang direkrut. Metode yang digunakan PT.. Ganda Prabu Nusantara yaitu metode terbuka dan tertutup. Dalam merekrut karyawan PT.. Ganda Prabu Nusantara memiliki kriteria tertentu yang harus dimiliki oleh calon karyawan, walaupun ada kendala-kendala tetapi ada upaya-upaya untuk mengatasinya. Saran-saran : diharapkan pimpinan PT. Ganda Prabu Nusantara dalam melaksanakan administrasi personalia harus ditingkatkan lagi agar mengalami peningkatan kinerja secara maksimal; adanya pelatihan-pelatihan dan adanya insentif yang memadai bagi karyawan berdasarkan kebijakan dari pimpinan.

Kata Kunci: implementasi pengelolaan, adminitrasi personalia

\section{A. Pendahuluan}

Perubahan situasi bisnis yang terjadi hampir setiap saat, baik kondisi internal maupun eksternal membuat semua jajaran pimpinan harus selalu jeli mencermatinya. Semua asumsi dalam perencanaan bisnis yang pernah sukses pada masa yang lalu harus selalu dikaji ulang. Perubahan-perubahan yang terjadi dipicu oleh berbagai faktor seperti kompetisi secara global, peraturan pemerintah, perubahan teknologi, kondisi ekonomi dan sebagainya akan mempengaruhi kelangsungan organisasi dimasa yang akan datang. Menghadapi hal ini organisasi dituntut untuk cepat tanggap terhadap kondisi yang terjadi dan memiliki kemampuan untuk dapat menyesuaikan.

Perubahan situasi bisnis yang terjadi hampir setiap saat, baik kondisi internal maupun eksternal membuat semua jajaran pimpinan harus selalu jeli mencermatinya. Semua asumsi dalam perencanaan bisnis yang pernah sukses pada masa yang lalu harus selalu dikaji ulang. Perubahan-perubahan yang terjadi dipicu oleh berbagai faktor seperti kompetisi secara global, peraturan pemerintah, perubahan teknologi, kondisi ekonomi dan sebagainya akan mempengaruhi kelangsungan organisasi dimasa yang akan datang. Menghadapi hal ini organisasi dituntut untuk cepat tanggap terhadap kondisi yang terjadi dan memiliki kemampuan untuk dapat menyesuaikan Organisasi masa depan adalah organisasi yang pembaruan, mudah menyesuaikan diri, dan merespon dengan cepat perubahan yang terjadi, sehingga organisasi akan mampu bertahan dan menang dalam persaingan. Di samping itu perusahaan juga dapat memegang kendali industrinya dengan menciptakan pasar di masa depan, oleh karena itu diperlukan pemimpin yang dapat meramu visi dan misinya, SDM, dan strategi bersaing agar dapat menciptakan organisasi kelas dunia.

Manusia merupakan sumber daya paling penting dalam suatu organisasi. Sumber daya manusia ini menunjang kelangsungan suatu organisasi dengan karya, bakat dan kreatifitas. Suatu organisasi yang memiliki teknologi canggih sekalipun tidak akan mampu mencapai tujuan organisasi tanpa adanya sumber daya manusia di dalamnya. Manusia sebagai salah satu sumber daya penting dalam suatu organisasi semakin di 
tuntut untuk memiliki keahlian dalam bidangnya masing-masing agar dapat melaksanakan suatu tugas atau pekerjaan. Keahlian tersebut sangat mempermudah seseorang dalam menyelesaikan setiap tugas yang diberikan oleh pimpinan.

Dengan keahlian juga, hasil dari pekerjaan yang dilakukan akan lebih baik. Selain faktor sumber daya manusia,pelaksanaan pekerjaan dapat berjalan dengan benar perlu adanya sistem pelaksanaan administrasi yang baik agar mencerminkan keberhasilan karyawan dalam melaksanakan sistem kerja dan juga kegiatan-kegiatan yang menunjang pelaksanaan administrasi. Pelaksanaan administrasi peersonalia diawali dengan proses perencanaan sumber daya manusia yaitu kegiatan yang dilakukan untuk menentukan kebutuhan sumber daya manusia suatu perusahaan. Dengan adanya perencanaan tersebut maka diharapkan suatu perusahaan dapat memperoleh tenaga kerja yang terampil dansesuai dengan yang dibutuhkan oleh perusahaan tersebut. Selanjutnya diperlukan proses rekrutmen yang baik. Proses rekrutmen yang baik sangat diperlukan oleh suatu perusahaan karena dengan rekrutmen suatu perusahaan dapat menyeleksi calon tenaga kerja dariberbagai latar belakang maupun keterampilan yang berbeda-beda. Dengan begitu suatu perusahaan dapat memperoleh tenaga kerja yang memiliki ketrampilan dan latar belakang yang baik atau maksimal.

Setelah proses rekrutmen seorang karyawan akan melalui tahap penempatan karyawan. Dimana seorang karyawan ditempatkan sesuai dengan bidang dan keahliannya masing-masing. Apabila dalam penempatan karyawan tidak sesuai dengan bidang dan keahliannya maka hal tersebut akan menimbulkan dampak yang kurang baik, diantarannya adalah turunnya semangat kerja karyawan, kurangnya tanggung jawab dan kekeliruan dalam melaksanakan pekerjaan kepegawaian berisi informasi mengenai seluruh karyawan yang ada di dalam perusahaan tersebut.

Organisasi adalah sistem yang menghubungkan sumber-sumber daya sehingga memungkinkan pencapaian tujuan atau sasaran tertentu. Organisasi merupakan perangkat sosial dan teknologis yang terdiri dari faktor-faktor manusia dan fisik. Dengan bantuan dari penerapan teknologi, manusia melaksanakan fungsi atau tugas yang menuntun pada tercapainya sasaran yang ditentukan secara rasional. Rancangan organisasi adalah langkah awal untuk melakukan pencarian tenaga kerja yang menjadi tanggung jawab utama bagi suatu manajemen personalia dalam menjalankan tugastugas yang telah ditetapkan pada pekerjaan tertentu untuk mencapai sasaran dan tujuan organisasi secara keseluruhan. Dalam buku "Manajemen Sumber Daya Manusia" yang ditulis oleh Suhendra, dikatakan bahwa perencanaan atau planning adalah kegiatan awal dalam sebuah pekerjaan dalam memikirkan hal-hal yang terkait dengan pekerjaan itu agar mendapatkan hasil yang optimal. Oleh karena itu perencanaan merupakan sebuah keniscayaan, sebuah keharusan, dan juga sebuah kebutuhan. Segala sesuatu memerlukan perencanaan tidak terkecuali dalam memilih jabatan atau karir (Suhendra, 2012:86)

Pada dasarnya pengembangan karir berorientasi pada perkembangan perusahaan dalam menjawab tantangan bisnis dimasa yang akan datang. Setiap perusahaan harus menerima kenyataan bahwa eksistensinya di masa depan tergantung pada karyawan itu sendiri. Perusahaan yang tidak memiliki karyawan yang kompetitif akan mengalami kemunduran dan akhirnya tersisih karena katidakmampuannya dalam menghadapi pesaing. Kondisi seperti ini mengharuskan perusahaan untuk melakukan pembinaan karir bagi para karyawan, yang dilaksanakan secara berencana dan berkelanjutan. Dengan kata lain pembinaan karir sebagai salah satu kegiatan Manajemen Personalia yang dilaksanakan sebagai kegiatan manajemen personalia lainnya. 
PT. Ganda Prabu Nusantara merupakan lembaga Diksar Satpam nomor 1 di Riau yang bekerja sama dengan Ditbinmas Polda Riau dimana pengajar dari Polda Riau. Dalam merekrut karyawan pihak PT. Ganda Prabu Nusantara tidak hanya menitikberatkan pada jenjang pendidikan calon karyawan akan tetapi mempertimbangkan aspek-aspek seperti keahlian, pengalaman kerja, dan tidak hanya dari segi ilmu pengetahuan tetapi juga ilmu agama terutama yang berkenaan dengan sistem operasional lembaga. Untuk melaksanakan tujuan dalam perencanaan rekrutmen tenaga kerja tersebut maka PT. Ganda Prabu Nusantara membutuhkan SDM yang berkualitas. Namun tidak semua organisasi atau instansi melaksanakan proses perencanaan, rekrutmen dan penempatan pegawai dengan baik. Masih ada instansi yang tidak melakukan perencanaan dalam perekrutan tenaga kerja. Hal tersebut menyebabkan proses rekrutmen berjalan kurang maksimal. Proses rekrutmen juga berjalan tidak sesuai dengan prosedur yang berlaku, masih ada kecurangan-kecurangan yang terjadi dalam proses ini. Selanjutnya untuk tahap penempatan pegawai juga belum berjalan dengan baik, hal tersebut dibuktikan dengan masih adanya pegawai yang ditempatkan tidak sesuai dengan bidang keahliannya.

PT. Ganda Prabu Nusantara untuk merekrut karyawan membutuhkan proses perencanaan tenaga kerja, karena agar dalam rekrutmen tidak ada kesalahan karyawan yang direkrut. Metode yang digunakan PT. Ganda Prabu Nusantara yaitu metode terbuka dan tertutup. Dalam merekrut karyawan PT. Ganda Prabu Nusantara memiliki kriteria tertentu yang harus dimiliki oleh calon karyawan. Masalah ini menarik minat peneliti untuk mengadakan penelitian yang mendalam mengenai implementasi pengelolaan administrasi personalia pada PT. Ganda Prabu Nusantara.

\section{B. Metodologi Penelitian}

Penelitian bertujuan menggali dan membangun suatu preposisi atau menjelaskan makna dibalik realita. Dalam penelitian kualitatif, peneliti berpijak dari realitas atau peristiwa yang berlangsung di lapangan (Bungin, 2010). Penelitian kualitatif adalah penelitian yang bermaksud untuk memahami fenomena tentang apa yang dialami oleh subyek penelitian (misalnya perilaku, persepsi, tindakan, dan lainnya), secara holistic, dan dengan cara deskripsi dalam bentuk kata-kata dan bahasa, pada suatu konteks khusus yang alamiah dan dengan memanfaatkan berbagai metode alamiah (Moleong 2006). Dalam penelitian kualitatif, data dituangkan secara deskriptif dalam bentuk laporan dan uraian (Nasution, 2001). Dalam penelitian kualitatif, data dituangkan secara deskriptif dalam bentuk laporan dan uraian (Nasution, 2001). Dalam penelitian kualitatif adalah penelitian yang berusaha mengungkapkan gejala secara menyeluruh dan sesuai dengan konteks melalui pengumpulan data dan latar alami dengan memanfaatkan diri peneliti di lapangan sebagai instrumen kunci. Dalam penelitian kualitatif tidak ditemukan adanya angka-angka yang di analisis menggunakan alat statistik, melainkan data diperoleh dari berbagai sarana yang dilakukan oleh peneliti, seperti wawancara, dokumentasi maupun pengamatan langsung. Metode penelitian yang digunakan dalam penelitian ini adalah studi deskriptif. Definisi ini menekankan bahwa studi deskriptif dilakukan untuk mengetahui dan menjadi mampu untuk menjelaskan karakteristik variabel yang diteliti dalam suatu situasi. Tujuan dari penelitian deskriptif adalah membuat deskripsi atau menggambarkan fakta-fakta. Peneliti akan memaparkan hal-hal yang berkaitan dengan implementasi pengelolaan administrasi personalia PT. Ganda Prabu Nusantara. Sedangkan menurut Arikunto 
(2001:122) metoda deskriptif adalah, "suatu penelitian yang dimaksudnya tidak menguji hipotesis tertentu tetapi menggambarkan tentang suatu variabel atau gejala". Jadi dengan demikian penelitian kualitatif dengan metode deskriptif adalah suatu jenis penelitian yang bertujuan untuk membuat deskripsi, gambaran atau lukisan secara sistematis, faktual dan akurat mengenai fenomena yang diselidiki. Dengan demikian penelitian deskriptif kualitatif adalah penelitian yang hanya menggambarkan suatu keadaan atau peristiwa tanpa ada menggunakan rumus statistik untuk mengolah data, sehingga hasil penelitian dinyatakan dalam bentuk kalimat dan uraian.

\section{Hasil dan Pembahasan}

\section{Implementasi Pengelolaan Administrasi Personalia pada PT. Ganda Prabu Nusantara Pekanbaru}

Dari hasil penelitian ditemukan bahwa perencanaan yang dilakukan di PT. Ganda Prabu Nusantara Pekanbaru dilakukan oleh direktur utama beserta staf seniornya, hal ini dimaksudkan untuk memperoleh suatu rencana yang matang mengenai program-program PT. Ganda Prabu Nusantara kedepan. Selain itu perencanaan juga sudah ditetapkan oleh pimpinan PT, Ganda Prabu Nusantara. Sesuai dengan pendapat ahli Adisasmita (2011:22) mengemukakan bahwa, "Pengelolaan bukan hanya melaksanakan suatu kegiatan, akan tetapi merupakan rangkaian kegiatan yang meliputi fungsi-fungsi manajemen, seperti perencanaan,pelaksanaan, dan pengawasan untuk mencapai tujuan secara efektif dan efisien."

Dari hasil penelitian berdasarkan wawancara penulis dengan HRD PT. Ganda Prabu Nusantara, Bapak Radika Prima KD. A.Md pada tanggal 6 Juni 2019 disampaikan bahwa perencanaan di PT. Ganda Prabu Nusantara dilakukan secara matang oleh para pengurus senior yang memiliki banyak pengalaman, para pegawai juga menganalisis kebutuhan terlebih dahulu baik dalam lingkung internal, ekternal, maupun dalam lingkungan organisasi hal ini dimaksudkan agar apa yang direncanakan kedepan dapat terealisir dengan baik sesuai dengan yang direncanakan. Sesuai dengan pendapat ahli Alex S. Nitisemito (2011::11) Manajemen Personalia adalah "suatu ilmu seni untuk melaksanakan antara planning, organizing, actuating, dan controlling, sehingga efektifitas dan efisiensi personalia dapat ditingkatkan semaksimal mungkin dalam pencapaian tujuan".

Pernyataan dari HRD PT. Ganda Prabu Nusantara di perkuat dengan adanya pernyataan dari manager operasional Bapak M. Akhir Harahap wawancara pada tanggal 7 Juni 2019 bahwa perencanaan pegawai di PT. Ganda Prabu Nusantara ini selalu direncanakan terlebih dahulu tentunya dengan melihat dari kebutuhan terlebih dahulu agar sesuai dengan apa yang di butuhkan oleh perusahaan sehingga kedepannya dapat mencapai apa yang diinginkan. Pembinaan dan orientasi bagi pegawai baru terhadap lingkungan perusahaan agar dapat mengenal lingkungan PT. Ganda Prabu Nusantara dengan baik sehingga akan muncul kenyamanan dalam dirinya pada saat bekerja nanti kemudian menempatkan pegawai baru sesuai dengan pada saat dia melamar pekerjaan. Perekrutan pegawai baru dilakukan hanya apabila perusahaan membutuhkan saja.

Sesuai dengan pendapat ahli Drs. M. Manulang (1990:15-17) dalam bukunya dasar-dasar manajemen istilah pengelolaan (manajemen) mengandung tiga pengetian, yaitu : pertama, manajemen sebagai suatu proses, kedua, manajemen sebagai kolektifitas orang-orang yang melakukan aktifitas manajemen dan yang ketiga, manajemen sebagai suatu seni (suatu arti) dan sebagi suatu ilmu. Menurut pengertian 
yang pertama yakni manajemen sebagai suatu proses, Dalam buku encyclopedia of the social sciences dikatakan bahwa manajemen adalah suatu proses dengan proses mana pelaksanaan suatu tujuan tertentu diselenggarakan dan diawasi. Sedangkan menurut pengertian yang kedua, manjemen adalah kolektivitas orang-orang yang melakukan aktivitas manajemen. Dan menurut pengertian yang ketiga, manajemen adalah suatu seni atau ilmu adalah seni dan ilmu perencanaan, pengorganisasian, penyusunan, pengarahan, dan pengawasan dari pada sumber daya manusia untuk mencapai tujuan yang sudah ditetapkan terlebi dahulu.

Dari hasil penelitian berdasarkan wawancara penulis dengan HRD PT. Ganda Prabu Nusantara, Bapak Radika Prima KD. A.Md pada tanggal 8 Juni 2019 menyampaikan bahwa perekrutan dan seleksi di PT. Ganda Prabu Nusantara ini terlebih dahulu melakukan analisis kebutuhan, kemudian menyebarluaskan informasi adanya lowongan baik secara internal maupun eksternal tetapi hanya dari mulut kemulut saja, setelah pelamar atau calon pegawai datang untuk melamar diterima berkas lamaran dan melakukan seleksi berkas lamaran, setelah itu memanggil calon pegawai yang lolos seleksi, berkas, kemudian mempersiapkan wawancara dengan direktur utama PT. Ganda Prabu Nusantara. Perekrutan pegawai baru di PT. Ganda Prabu Nusantara dilakukan hanya apa bila perusahaan membutuhkan saja, sehingga sebelum melakukan pengrekrutan direktur utama dan para pegawai menganalisis kebutuhan terlebih dahulu.

Dari hasil penelitian ditemukan bahwa Perencanaan karir dan pengembangan termasuk sebagai program pembinaan tenaga kerja. Tinjauan kegiatan pembinaan Ini adalah untuk memelihara pegawai dengan cara mengembangkannya, sesuai dengan bakat dan kemampuannya, agar bisa berfungsi dengan baik dan optimal bagi perusahaan.. Fungsi pembinaan ini biasanya merupakan tanggung jawab langsung dari pimpinan PT. Ganda Prabu Nusantara .sebagai direktur utama yang bertanggungjawab untuk mengembangkan pengetahuan dan keterampilan bawahannya, sehingga bawahan menjadi lebih cakap dan terampil berdasarkan hasil wawancara dengan pimpinan PT. Ganda Prabu Nusantara Pekanbaru.

Sesuai dengaan pendapat Manulang (2001: 156), manajemen personalia adalah sebuah bidang ilmu yang mempelajari tentang bagaimana cara memberikan suatu fasilitas untuk perkembangan, pekerjaan, dan juga rasa partisipasi pekerjaan di dalam suatu kegiatan atau aktivitas. Dari hasil penelitian berupa wawancara penulis dengan Kapusdik PT. Ganda Prabu Nusantara, Bapak Halomoan Lubis pada tanggal 12 Juni 2019 yang menyatakan bahwa semua pegawai di PT. Ganda Prabu Nusantara mempunyai perencanaan terhadap karirnya, bahkan selain rajin mengikuti pelatihan ada yang masih melanjutkan kuliah dan berharap mampu menambah dan mengembangkan kompetensi yang dimiliki.. kaaryawan administrasi yang mengerjakan pekerjaan yang agak berat selalu diberikan uang tambahan sesuai dengan kebijakan pimpinan PT. Ganda Prabu Nuaantara. Dari hasil penelitian berupa wawancara penulis dengan bagian keuangan, Bapak Solehuddin, SE pada tanggal 15 Juni 2019 disebutkan bahwa kompensasi karyawan PT. Ganda Prabu Nusantara berupa gaji pokok dan tunjangan saja Tetapi ada satu atau dua karyawan yang mendapatkan kompensasi diluar gaji pokok, sekedar memberikan tips karena mengerjakan pekerjaan yang dilihat lumayan berat dan tidak sesuai dengan gaji pokok. Seperti karyawan administrasi. Kompensasi yang didapatkan sesuai dengan gaji dan tunjangan tidak lebih tidak kurang sesuai dengan jabatan. 
Hasil temuan penelitian berdasarkan wawancara penulis dengan direktur utama PT. Ganda Prabu Nusantara Bapak Ridho Rustar Mulyadi pada tanggal 17 Juni 2019 disebutkan bahwa seorang pemimpin hanya berusaha untuk memberikan feedback (timbal balik) yang baik kepada staf administrasi dan pembina pada PT.Ganda Prabu Nusantara ini dengan memanusiakan manusia. Pernyataan diperkuat oleh eksekutif marketing Bapak Zulkifli pada tanggal 18 Juni 2019 yang menyatakan bahwa pimpinan PT. Ganda Prabu Nusantara bisa memahami kemampuan para karyawan administrasi dan pembina, pimpinan selalu memberikan pekerjaan yang sesuai dengan kemampuan yang saya miliki. pimpinan juga tidak segan-segan memuji bawahannya yang berprestasi, memberikan pengarahan serta bimbingan kepada karyawan atau pembina yang belum mengerti terhadap sesuatu. Selain menjadi pimpinan, beliau selalu berbagi pengetahuan, berbagi pengalaman, serta pengarahan bagaimana cara menjadi pembina yang baik.' Memberikan motivasi kepada para karyawan merupakan kewajiban para pimpinan, agar para karyawan tersebut dapat lebih meningkatkan volume dan mutu pekerjaan yang menjadi tanggungjawab.

Sesuai dengan pendapat Flippo (Handoko; 2000:6), pengertian manajemen personalia adalah perencanaan, pengorganisasian, pengarahan dan pengendalian atas pengadaan tenaga kerja, pengembangan, kompensasi, integrasi, pemeliharaan dan pemutusan hubungan kerja dengan sumber daya manusia untuk mencapai sasaran perorangan, organisasi, dan masyarakat. Dari temuan penelitian mengenai kepuasan kerja merupakan keadaan emosional yang menyenangkan atau tidak menyenangkan bagi para pegawai memandang pekerjaan mereka. Kepuasan kerja mencerminkan perasaan seseorang terhadap pekerjaannya.Ini tampak pada sikap positive pegawai terhadap pekerjaan dan segala sesuatu yang dihadapi di lingkungan kerjanya. Dari hasil wawancara penulis dengan pimpinan PT. Ganda Prabu Nusantara, Bapak Ridho Rustar Mulyadi pada tanggal 20 Juni 2019 disampaikan bahwa pimpinan selalu memberikan pengertian, memberikan pekerjaan yang sesuai dengan kemampuan atau karakter para karyawan administrasi dan pembina pada PT. Ganda Prabu Nusantara.

Sesuai dengan pendapat George R. Terry yang di kutip oleh H. Hadari Nawawi (2003:2880 manajemen adalah "pencapaian tujuan (organisasi) yang sudah ditentukan sebelumnya dengan mempergunakan bantuan orang lain" Dari hasil penelitian berdasarkan wawancara penulis dengan pimpinan PT. Ganda Prabu Nusantara, Bapak Ridho Rustar Mulyadi pada tanggal 25 Juni 2019 dinyatakan bahwa seorang pemimpin hanya berusaha memberikan timbal balik atas pekerjaan yang telah diselesaikan oleh para tenaga pembina. Memberikan hak mereka, memberikan pengarahan, menjadi pemimpin, partner dalam bekerja, berusaha memahami setiap karakter bawahan, menerima aspirasi mereka, mencari jalan keluar dari setiap permasalahan, dan menyatukan pendapat mereka.

Dari hasil penelitian berdasarkan wawancara HRD, Bapak Radika Prima KD. A.Md pada tanggal 26 Juni 2019 disampaikan terkadang menjadi seorang pemimpin, menjadi partner dalam bekerja, pemimpin mampu memposisikan diri, sehingga mampu bekerja, tidak membuat segan para karyawannya. pemimpin mampu menjadi contoh untuk para pegawainya, mampu memberikan solusi, mampu menjadi partner bagi bawahannya, menerima segala pendapat yang bawahannya sampaikan, mampu mengambil keputusan. Dari hasil temuan penelitian PT. Ganda Prabu Nusantara yang berhasil biasanya selalu memperhatikan kebutuhan-kebutuhan para pegawainya dan melindungi mereka dari kecelakaan-kecelakaan kerja. Mereka menyadari bahwa keberhasilan organisasi dalam mencapai tujuannya bergantung pada kemampuan para 
anggotanya, oleh karena itu sangatlah perlu diperhatikan keamanan dan kenyamanan kerjanya.

Hasil penelitian berdasarkan wawancara penulis dengan eksekutif marketing, Bapak Zulkifli pada tanggal 27 Juni 2019 disampaikan bahwa pemeliharaan sumber daya manusia dilakukan dengan cara menciptakan komunikasi dengan baik pada saat bekerja, saling terbuka antara pemimpin dan bawahan dalam sebuah pekerjaan, peka terhadap lingkungan. Saling terbuka antar pemimpin dan bawahan itu yang selalu diterapkan oleh pimpinan dalam sebuah pekerjaan. Peka terhadap lingkungan sekitar. Pimpinan selalu berkomunikasi dengan baik kepada para pegawai dalam bekerja, dan peka terhadap lingkungan sekitar perusahaan tidak memberikan pekerjaan kepada pegawai yang bukan bidangnya atau yang tidak memahami pekerjaan tersebut. Pemeliharaan terhadap para pegawai sangatlah penting, karena sebuah organisasi tidak akan bisa berjalan tanpa adanya anggota dalam organisasi.

Sesuai dengan pendapat ahli T. Hani Handoko (2000:30 Manajemen Personalia yaitu "suatu proses penarikan, seleksi, penempatan, pemeliharaan, dan pengembangan sumber daya manusia untuk mencapai tujuan organisasi.

\section{Kendala-Kendala yang Dihadapi Dalam Implementasi Pengelolaan Administrasi Personalia Pada PT. Ganda Prabu Nusantara Pekanbaru}

Dari hasil penelitian ditemukan kendala-kendala yang dihadapi dalam implementasi pengelolaan administrasi personalia adalah sebagai berikut: Hasil penelitian berdasarkan wawancara penulis dengan manager operasional, Bapak M. Akhir Harahap pada tanggal 2 Juli 2019 menyampaikan paling dominan kesulitan dalam meramalkan perencanaan kedepannya itu. Karena yang terjadi dimasa depan belum tentu terjadi sesuai dengan yang dibayangkan sekarang. Paling dominan kesulitan dalam meramalkan sebuah perencanaan, dapat dikatakan hambatan selain meramalkan perencanaan adalah adanya tenaga-tenaga lama dengan pola pikir yang masih konvensional, namun dengan dedikasi dan loyalitas yang tinggi justru menjadi penyemangat bagi tenaga personalia lainnya yang masih muda, jadi disamping mereka dikatakan sebagai faktor penghambat, disisi lain mereka juga menjadi aset yang berharga bagi lembaga.

Hasil penelitian berdasarkan wawancara HRD, Bapak Radika Prima KD. A.Md dari wawancara penulis dengan 3 Juli 2019 disampaikan yang paling dominan adalah kesulitan meramalkan perencanaan untuk kedepannya, karena pastinya tidak akan tahu apa yang akan terjadi dimasa yang akan datang. Kesulitan meramalkan perencanaan karena yang akan terjadi dimasa depan belum tentu sesuai dengan yang dibayangakan sekarang. Bukan hanya dalam pelaksanaan manajemen personalia di PT. Ganda Prabu Nusantara saja yang mengalami kendala. Dalam semua kegiatan juga pasti akan menemukan kendala tetapi, disamping itu ada pula faktor pendukung yang akan memperlancar proses berjalannya suatu kegiatan.

Praktek yang sehat dalam melaksanakan tugas dan fungsi setiap unit organisasi pada perusahaan tersebut sudah dilaksanakan dengan baik., hanya saja terdapat sedikit kekurangan yaitu tidak adanya nomor urut tercetak pada setiap formulir yang digunakan. Dibubuhkannya nomor urut tercetak pada setiap dokumen yang digunakan berguna untuk menghindari perangkapan dokumen dan mempermudah penelusuran dokumen, sehingga dapat meningkatkan pengendalian. 
Seluruh dokumen dan dokumen pendukung yang digunakan oleh perusahaan belum bernomor urut tercetak. Nomor yang tercantum dalam setiap dokumen hanya nomor formulir dan unit perusahaan yang bertanggung jawab atas dokumen tersebut. Penulis melihat hal ini merupakan suatu kelemahan yang dimiliki oleh perusahaan. Meskipun dokumen ini tidak bersangkutan dengan keuangan akan tetapi dapat mempengaruhi pengendalian intern dalam perusahaan, karena apabila ada dokumen yang hilang pengendalian ini merupakan pengendalian untuk kelengkapan data.

\section{Upaya-Upaya yang Dilakukan Untuk Mengatasi Kendala Dalam Implementasi Pengelolaan Administrasi Personalia pada PT. Ganda Prabu Nusantara Pekanbaru}

Hasil penelitian yang ditemukan adapun upaya-upaya yang dilakukan untuk mengatasi kendala dalam implementasi pengelolaan administrasi personalia pada PT. Ganda Prabu Nusantara sebagai berikut: Petama, Pada PT. Ganda Prabu Nusantara dari semua elemen dapat dikatakan sebagai pendukung bagi pelaksanaan manajemen personalia, karena mulai dari personalnya hingga lingkungan kerja yang kondusif menjadikan kinerja personalia berjalan lancar dan efektif tanpa kendala yang berarti. Sedangkan pendukung pelaksanaan manajemen personalia secara keseluruhan.

Kedua, dari hasil penelitian berdasarkan wawancara menurut HRD, Bapak Radika Prima KD. A.Md pada tanggal 4 Juli 2019 disampaikan adanya sarana dan prasarana yang memadai dan lingkungan yang kondusif, adanya kebijakan dari pimpinan yang mengharuskan kepada setiap bidang untuk memperbaiki dan meningkatkan kualitas perusahaan, Skill dan kompetensi yang tinggi dari setiap personel perusahaan, juga memiliki visi dan misi yang jelas. Kemudian selain beberapa faktor ada pula Sistem informasi yang relatif mudah untuk diakses itu juga memudahkan kerja personel. Memiliki kedisiplinan yang tinggi dari para personel. Itu faktor-faktor yang dimiliki.

Ketiga, PT. Ganda Prabu Nusantara sebagai penunjang proses berjalannya manajemen personalia. Pada PT. Ganda Prabu Nusantara telah dapat digolongkan sebagai salah satu contoh perusahaan yang menyediakan jasa keamanan/security, akan tetapi dirasa masih belum maksimal, sebab apa yang didapatkan sekarang masih bisa ditingkatkan lagi kedepannya.

Keempat, dari hasil penelitian berdasarkan wawancara dengan HRD diperkuat dengan adanya pernyataan dari manager operasional, Bapak M. Akhir Harahap berdasarkan wawancara pada tanggal 8 Juli 2019 disampaikan adanya pimpinan perusahaan yang profesional, lingkungan perusahaan yang kondusif dan ditunjang oleh sarana dan prasarana yang memadai, perusahaan memiliki visi dan misi yang jelas, kompetensi yang tinggi dari setiap personel PT. Ganda Prabu Nusantara. Adanya pimpinan PT. Ganda Prabu Nusantara yang professional, pimpinan memiliki visi dan misi yang jelas, lingkungan yang kondusif serta di tunjang dengan sarana dan prasarana yang memadai, adanya kebijakan pimpinan yang mengharuskan kepada setiap unit perusahan yang ada untuk memperbaiki serta meningkatkan kualitas perusahaan.

Kelima, dari hasil penelitian berdasarkan wawancara penulis dengan eksekutif marketing, Bapak Zulkifli pada tanggal 10 Juli 2019 yang menyampaikan bahwa letak PT. Ganda Prabu Nusantara ramai akan penduduk sehingga jaringan sekitar perusahaan ini sangat bagus sehingga bisa mengakses informasi dengan cepat. Pada dasarnya setiap individu yang bekerja dengan dedikasi yang tinggi dan jugas 
kepercayaan yang tinggi akan menghasilkan suatu karya yang dapat dipertanggungjawabkan.

Keenam, dalam menerima calon karyawan PT. Ganda Prabu Nusantara menerima karyawan yang sesuai dengan bidang yang dibutuhkan dan melakukan seleksi melalui tes tertulis untuk bidang yang membutuhkan keahlian tertentu, psikotes, dan wawancara. Berdasarkan wawancara dapat disimpulkan bahwa seleksi calon karyawan berdasarkan persyaratannya.

Ketujuh, evaluasi atas hasil kerja karyawan ini dilakukan untuk mengetahui kompetensi karyawan terhadap tugas dan tanggung jawabnya. Jika dinilai baik karyawan tetap pada posisinya atau dipromosikan atau dapat pula dimutasikan. Dengan adanya promosi dan mutasi maka akan terjadi perputaran jabatan dengan tujuan agar karyawan dapat terampil dibidang lain selain jabatan yang sebelumnya dan juga menghindari terjadinya kolusi antar karyawan yang nantinya berakibat merugikan perusahaan.

Kedelapan, sebelum memulai kerja biasanya para calon karyawan diberikan pelatihan kerja untuk melatih karyawan baru mengenai pekerjaan yang akan menjadi tanggung jawabnya, dan bagi karyawan yang lama perusahaan tetap melakukan pelatihan secara berkesinambungan.

\section{Penutup}

Berdasarkan uraian-uraian yang telah dikemukakan di atas, maka kesimpulan yang dapat penulis ambil adalah: Implementasi pengelolaan adminiistrasi personalia pada PT. Ganda Prabu Nusantara adalah dalaam merekrut karyawan membutuhkan proses perencanaan tenaga kerja, karena agar dalam rekrutmen tidak ada kesalahan karyawan yang direkrut. Metode yang digunakan PT. Ganda Prabu Nusantara yaitu metode terbuka dan tertutup. Dalam merekrut karyawan PT. Ganda Prabu Nusantara memiliki kriteria tertentu yang harus dimiliki oleh calon karyawan. Adanya kendalakendala yang ditemukan seperti adanya tenaga-tenaga lama dengan pola pikir yang masih konvensional; . Kesulitan meramalkan perencanaan karena yang akan terjadi dimasa depan belum tentu sesuai dengan yang dibayangakan sekarang; yaitu tidak adanya nomor urut tercetak pada setiap formulir yang digunakan; dokumen dan dokumen pendukung yang digunakan oleh perusahaan belum bernomor urut tercetak. Nomor yang tercantum dalam setiap dokumen hanya nomor formulir dan unit perusahaan yang bertanggung jawab atas dokumen tersebut. Upaya-upaya yang dilakukann untuk mengatasi kendala dalam implementasi pengelolaan administrasi personalia pada PT. Ganda Prabu Nusantara sebagai berikut : semua elemen dapat dikatakan sebagai pendukung bagi pelaksanaan manajemen personalia; adanya sarana dan prasarana yang memadai dan lingkungan yang kondusif, adanya kebijakan dari pimpinan yang mengharuskan kepada setiap bidang untuk memperbaiki dan meningkatkan kualitas perusahaan, Skill dan kompetens yang tinggi dari setiap personel perusahaan, juga memiliki visi dan misi yang jelas; letak PT. Ganda Prabu Nusantara ramai akan penduduk sehingga jaringan sekitar perusahaan ini sangat bagus sehingga bisa mengakses informasi dengan cepat; adanya promosi dan mutasi maka akan terjadi perputaran jabatan dengan tujuan agar karyawan dapat terampil dibidang lain selain jabatan yang sebelumnya dan juga menghindari terjadinya kolusi antar karyawan yang nantinya berakibat merugikan perusahaan; para calon karyawan diberikan pelatihan kerja untuk melatih karyawan baru mengenai pekerjaan yang akan 
menjadi tanggung jawabnya, dan bagi karyawan yang lama perusahaan tetap melakukan pelatihan secara berkesinambungan.

\section{Daftar Pustaka}

Alex S. Nitisemito, 2011. Manajemen Personalia (Manajemen SDM), (akarta; Ghalia Indonesia.

Bungin, B.M., 2010, Penelitian Kualitatif, Jakarta, PT. Kencana..

Edward III, George C (edited). 1984. Public Policy Implementing. Jai Press Inc, London-England.

Erni Tisnawati Sule, Kurniwan Saefullah. 2009. Pengantar Manajemen, Jakarta : Kencana Perdana Media Goup

Daryanto, 2011. Kamus Indonesia Lengkap. Surabaya : Apollo.

M. Manulang, 2011. Dasar-Dasar Manajemen, Jakarta : Ghalia Indonesia.

Gouzali Saydam. 2000. Manajemen Sumber Daya Manusia (Human Resources Management) suatu pendekatan Mikto, Jakarta: Djambatan Karya Unipress.

Guntur Setiawan. 2004. Implementasi Dalam Birokrasi Pembangunan. Bandung: Remaja Rosdakarya Offset.

Grindle, Merilee S. 1980. Politics and Policy Implementation in The Third World. New Jersey : Princnton University Press

Hadari Nawawi. 2003. Manajemen Sumber Daya Manusia; untuk Bisnis yang Kompetitif, (Yogyajarta: Gadjah Mada University Press.

Hanifah Harsono. 2002. Implementasi Kebijakan dan Politik. Bandung: Mutiara Sumber Widya.

Mazmanian, Daniel A and Paul A. Sabatier. 1983. Implementation and Public Policy. USA: Scott Foresman and Company.

Miles dan Huberman. 2010. Analisis Data Kualitatif. Jakarta : UI Press

Suharsimi Arikunto. 2011. Prosedur Penelitian Suatu Pendekatan Praktek. Jakarta : Rineka Cipta.

T. Hani Handoko, 2000. Manajemen Personalia, Yogyakarta; BPFE.

Nurdin dan Usman. 2002. Konteks Implementasi Berbasis Kurikulum. Jakarta: PT. Raja Grafindo Persada. 